\title{
Pelvic and Testicular Biometry of Sahel Goats in Maiduguri, Nigeria
}

\author{
${ }^{1}$ Abba, A., ${ }^{2 *}$ Mustapha, A. R., ${ }^{1}$ Bamanga, U. M., ${ }^{2}$ Iliyasu, D., ${ }^{2}$ Peter, I. D., ${ }^{2}$ Asuku, S. O., \\ ${ }^{2}$ Stephen, J. and ${ }^{2}$ Waziri, M. A.
}

${ }^{1}$ Veterinary Teaching Hospital, University of Maiduguri

${ }^{2}$ Department of Theriogenology, Faculty of Veterinary Medicine, University of Maiduguri, P.M.B 1069, Maiduguri

*Author for Correspondence: madambe72@gmail.com

\begin{abstract}
This study was carried out to document the pelvic and testicular biometric characteristics of Sahel goats. Record of body weight, body condition score, height at withers, scrotal length, scrotal circumference and external pelvic circumference were obtained from 400 male and 600 female Sahel goats. All the goats were approximately 1.5 years old and weighing 14 to $18 \mathrm{~kg}$, with body condition score of 3 or 4 (scale of 1-5). The mean bodyweight of Sahel bucks was $15.12 \pm 1.10 \mathrm{~kg}$ while that of Sahel does was $13.22 \pm 1.12 \mathrm{~kg}$, height at withers in bucks and does were $52.22 \pm 1.20 \mathrm{~cm}$, and $48.13 \pm 1.23 \mathrm{~cm}$ respectively. The scrotal length and circumference in Sahel bucks were $11.39 \pm 1.12 \mathrm{~cm}$ and $17.95 \pm 1.21 \mathrm{~cm}$ respectively. The external pelvic circumference in Sahel does was $55.13 \pm 1.16 \mathrm{~cm}$. There was significant $(\mathrm{P}<0.05)$ positive correlation between the body weight and body condition score in bucks $(r=0.52)$ and in does $(\mathrm{r}=0.42)$. It was observed that there was weak but positive correlation between the body weight and height at withers $(r=0.34)$, in bucks and in does $(r=0.25 ; \mathrm{P}<0.5)$. A low but significant positive correlation was found between the body weight and scrotal circumference $r=0.28,(\mathrm{P}<0.05)$ in bucks. There was a high and significant positive correlation between the scrotal length and scrotal circumference $r=0.66,(\mathrm{P}<0.05)$. The external pelvic circumference in Sahel does was also significantly positively correlated with body weight $r=0.40,(\mathrm{P}<0.05)$ and with the body condition score $r=0.33,(\mathrm{P}<0.05)$. The information obtained from this study can be used for breed -specific morphometric characterization of indigenous Sahel goats.
\end{abstract}

Keywords: Biometry; Pelvic circumference; Sahel goat; Testicular parameters

\section{INTRODUCTION}

Goats are important livestock species throughout Africa (Dehouegnon, 2017). Surveys have shown that up to 85 percent of rural households, poor farmers and small-time business people of all age groups and sexes keep goats (Salako, 2004). The world population of goats was estimated at 746 million, with $96 \%$ of these being kept in developing countries, however, they constitute the largest group of small ruminant livestock in Nigeria (53.8 million) and also constituting 6.2 percent of the World's goat population (FAOSTAT, 2008).

The Nigerian indigenous goats have been phenotypically classified into three distinct breeds, the Red Sokoto goat found mostly in the North Western Nigeria, the West African dwarf goats commonly found in the Middle belt and Southern part of Nigeria and the Sahel desert or West African longlegged goat found mostly in the North-Eastern Nigeria (Onakpa et al., 2010). Kwari, (2001) reported that, a pure Sahel goat are thin in appearance with narrow body, shallow chest, stiff short hair, long legs, with pendulous or semi- pendulous ears, and their colors varies from cream to red, black, pure white, gray, brown, or mixtures of colors.

In addition, Kwari (2001), stated that there were several ecotypes (brown, black, and mixed) of Sahel goats. Furthermore, the Sahel goats had higher resistance to dehydration and wide range of feeding habits that enables them to thrive in dry arid regions such as the Sahel.

In Nigeria, Sahel goats are found in the arid and semi-arid zones of Northern part of the country, mainly kept for agricultural, economic, cultural and religious purposes, and it is a resourceful and efficient ruminant producing meat, milk, skin and hair (Morand et al., 2004). The doe reach puberty between 4 to 12 months of age, and a buck can reach puberty as early as 4 months of age depending on the breed, season of birth, level of nutrition, and overall health status (Jamie and Clifford, 2014). It has been shown that Sahel does attain puberty at 5 months with presence of corpus luteum in the ovary (Bukar et al., 2006).

Live body weight is often the most common and informative measure of animal reproductive performance (Adeyinka and Mohammed, 2006). Testicular biometrics has been reported 
to be correlated parameters of male fertility such as semen production (Sameh et al., 2019). Raji et al. (2008) reported that live body weight in goat is often unavailable to goat's producers under field conditions in Nigeria, however, decision making on the field is sometimes difficult and husbandry techniques like animal medication are usually based on subjective estimates of body weight, therefore, studies have indicated that scrotal circumference is one of the most heritable components of fertility in ruminants and should be included in the breeding soundness evaluation in farm animals (Mohamed et al., 2020).

Thus, there is need to determine some measurable indices (body weight, body condition score, scrotal length, scrotal circumference, height at withers and external pelvic circumference) to assist in breeding soundness and serve as guide for the selection of male and female Sahel goats for breeding in Maiduguri and its environs. This information will be useful and serve as a baseline for future genetic improvement programs.

\section{MATERIALS AND METHODS}

\section{Experimental Animals and Management}

This study was conducted in Maiduguri, Nigeria during a two weeks goat quarantine operation from 10th - 25th March, 2019. The quarantine was for a governmental program designed for livestock restocking and distribution to internally displaced persons in some local government areas of Borno State. A total of 1000 apparently healthy Sahel goats (with specified age, weight and body condition score) as specified on the contract terms were purchased from livestock markets in Borno and Yobe States. All the 1000 goats had characteristics described for the Sahel goat ecotypes as described by Kwari (2001). The goats were provided shelter and fed with groundnut hay; wheat offal and water were provided ad libitum.

The goats were matured based on the appearance of their permanent teeth as described by Amin et al. (2016) and USDA (2019). Individual goats were weighed using SALTER ${ }^{\circledR}$ hanging spring balance (Nongo and Akinboade, 2013) and their weight ranges from $14-18 \mathrm{~kg}$. Goats with Body Condition Score (BCS) of 3 or 4 were selected into quarantine operation ( $1=$ very thin, $2=$ thin, $3=$ average, $4=$ fat and $5=$ very fat/obese) according to the method described by Burkholder (2000) and Bukar et al. (2012).

Out of the 1000 Sahel goats studied, 600 were females and 400 were males. The animals were selected using systematic sampling technique from a pooled of 4500 Sahel goats.

\section{External Pelvic Circumference}

The external pelvic circumference of the Sahel does were measured using a flexible measuring tape as described by Samuel and Salako, (2008). It is the distance $(\mathrm{cm})$ around the pelvis, over the tuber coxae and anterior part of the udder.

\section{Testicular Morphometry}

The scrotal circumference was measured using a flexible measuring tape (cm) (Ahmed et al., 2005; Memon et al., 2007). The testes are gently and firmly pushed into the scrotal sac and the circumference around the middle of the testicles was measured (Kumbhar et al., 2017). The scrotal length was measured as distance $(\mathrm{cm})$ between the lower end and neck of the scrotum as described by Raji et al. (2008).

The height at withers (meters) was measured as the vertical distance from the shoulder, at the withers, to the ground (Hifzan et al., 2015), as illustrated below.

\section{Statistical Analyses}

All data were analyzed using SPSS ${ }^{\circledR}$ statistical software version 20. Data were summarized using descriptive statistics and were expressed as Mean \pm Standard deviation. Correlation analyses were done for pelvic morphometric and testicular biometry in the Female and Male Sahel goats respectively. The correlations were considered significant at $\mathrm{P}<0.05$

\section{RESULTS}

The mean values obtained for body weights of Sahel goat bucks and does recorded in this study were $15.12 \pm 1.10 \mathrm{~kg}$ and $13.22 \pm 1.1 \mathrm{~kg}$, respectively. The mean values for height at withers was $52.22 \pm 1.20 \mathrm{~cm}$ in bucks and $48.13 \pm 1.23 \mathrm{~cm}$ in does. The values documented for scrotal length in this study was $11.39 \pm 1.12 \mathrm{~cm}$. The values of scrotal circumference recorded in the current studies was $17.95 \pm$ $1.21 \mathrm{~cm}$, while that of external pelvic circumference in Sahel does was $55.13 \pm 1.16 \mathrm{~cm}$ (Table 1 and 2).

The result from this study confirms that, body weight and body condition scores were significantly correlated $(\mathrm{P}<0.05)$ in both male and female Sahel goats $(\mathrm{r}=0.52$; bucks and $\mathrm{r}=0.42$; does). There was weak but positive correlation between the body weight and height at withers at $\mathrm{r}=0.25$ in Sahel does and $\mathrm{r}=0.34$ in bucks. In this study, weak positive correlation $(\mathrm{P}<0.05)$ was found between the body weight and scrotal circumference $(\mathrm{r}=0.28)$ in Sahel bucks. There was moderate positive correlation between the scrotal length and scrotal circumference $(\mathrm{r}=0.66)$ (Table 3 and 4).

\section{DISCUSSION}

The mean values obtained for body weight of Sahel bucks and does recorded in this study was similar to $14.0 \pm 1.1 \mathrm{~kg}$ reported by Abba and Igbokwe, (2015) in Sahel goats in Nigeria. Ebegbulem et al. (2011) and Okpeku et al. (2011) reported similar live body weight of $13.46 \pm 0.54 \mathrm{~kg}$ in does and $15.37 \mathrm{~kg}$ in bucks respectively in West African Dwarf goats.

The values for height at withers was higher than $31.30 \pm 1.30$ $\mathrm{cm}$ reported by Samuel and Salako (2008) in West African dwarf (WAD) goats, these attributed to the short-legged and small-bodied size of WAD, similarly; Josue (2018) reported a mean value of $60 \pm 1.12 \mathrm{~cm}$ in rural African goats. The values documented for scrotal length in this study was similar to $12.91 \pm 0.12 \mathrm{~cm}$ in Red Sokoto goat but lower than in Borno white $(15.12 \pm 0.17 \mathrm{~cm})$ goats. The Borno white goat had significantly $(\mathrm{P}<0.05)$ longer scrotal length when compared with Red Sokoto goats (Raji et al., 2008).

The values of scrotal circumference recorded in the current studies was in agreement with $17.5 \pm 1.4 \mathrm{~cm}$ in red Sokoto 
bucks by Ajani et al. (2015) and $17.15 \pm 1.14 \mathrm{~cm}$ reported by Oyeyemi et al. (2011) in west African Dwarf bucks. Amare and Kefelegn, (2017) reported scrotal length of $20.8 \pm 1.84$ $\mathrm{cm}$ in indigenous breed of goats in the arid and semi-arid agro-ecological zones of Ethiopia. The slight difference could have been attributed to breed variation and management system among the two breeds.

Table 1: Body weight, body condition score, height at withers, scrotal length and scrotal circumference of Sahel bucks in Maiduguri.

\begin{tabular}{ll}
\hline Parameters $(\mathbf{n}=\mathbf{4 0 0})$ & Mean \pm SD \\
\hline Body weight $(\mathrm{kg})$ & $15.12 \pm 1.10$ \\
Height at withers $(\mathrm{cm})$ & $52.22 \pm 1.20$ \\
Scrotal length $(\mathrm{cm})$ & $11.39 \pm 1.12$ \\
Scrotal circumference $(\mathrm{cm})$ & $17.95 \pm 1.21$ \\
\hline
\end{tabular}

Table 2: Body weight, body condition score and external pelvic circumference of Sahel does in Maiduguri

\begin{tabular}{ll}
\hline Parameters $(\mathbf{n}=\mathbf{6 0 0})$ & Mean \pm SD \\
\hline Body weight $(\mathrm{kg})$ & $13.22 \pm 1.12$ \\
Height at withers $(\mathrm{cm})$ & $48.13 \pm 1.23$ \\
Pelvic circumference $(\mathrm{cm})$ & $55.11 \pm 1.16$ \\
\hline
\end{tabular}

Table 3: Correlation between the body weights, body condition score, with testicular measurement of Sahel bucks in Maiduguri

\begin{tabular}{lll}
\hline & Correlation Coefficient $(\boldsymbol{r})$ & P Value \\
\hline Scrotal length and Scrotal Circumference & 0.63 & $\mathrm{P}<0.000$ \\
Body Weight and Scrotal Circumference & 0.28 & $\mathrm{P}<0.002$ \\
Body Weight and body condition Score & 0.52 & $\mathrm{P}<0.000$ \\
Body Weight and Height at withers & 0.34 & $\mathrm{P}<0.001$ \\
\hline
\end{tabular}

The correlation coefficient $(r)$ is significant at $\mathrm{P}<0.05$.

Table 4: Correlation between the body weights, body condition score, with external pelvic circumference of Sahel does in Maiduguri

\begin{tabular}{llc}
\hline Parameters (600) & Correlation Coefficient $(\boldsymbol{r})$ & P Value \\
\hline Body Weight and Pelvic Circumference & 0.40 & $\mathrm{P}<0.000$ \\
Body condition Score and Pelvic Circumference & 0.33 & $\mathrm{P}<0.000$ \\
Body Weight and body condition Score & 0.42 & $\mathrm{P}<0.000$ \\
Body Weight and height at withers & 0.25 & $\mathrm{P}<0.000$ \\
\hline
\end{tabular}

The correlation coefficient $(r)$ is significant at $\mathrm{P}<0.05$.

The value documented for the external pelvic circumference in Sahel does was lower than $76 \pm 1.20 \mathrm{~cm}$ already documented by Dereje et al. (2013) in Hararghe Highland goat in Ethiopia. The variability between the breeds could be due to breed and ecological differences.

The correlation between body weight and body condition score in both males and females Sahel goats $r=0.52$ (bucks) and $\mathrm{r}=0.42$ (does) was similar to what was reported by Dereje et al. (2013), which stated that a correlation coefficient of $\mathrm{r}=0.47$ in bucks and $\mathrm{r}=0.48$ in does were documented in Hararghe Highland Goat in Ethiopia, furthermore, Turkgeldi et al. (1997) reported a correlation coefficient $(\mathrm{r}=0.52)$ in British crossbreed goat.

The weak positive correlation between the body weight and height at withers is similar to $\mathrm{r}=0.25$ reported by Babale $e t a l$.
(2018) in Sheep and goats in Adamawa State, Nigeria. Muhammad et al. (2006) reported highly significant correlation $(\mathrm{P}<0.05)$ between body weight and height at withers at $\mathrm{r}=0.54$ in local goat in Pakistan, however, Alemayehu et al. (2010) reported $\mathrm{r}=0.50$ in local sheep and goats in Ethiopia.

Similarly, a weak positive correlation between the body weight and scrotal circumference of Sahel goat buck was in contrast to the report of Adedeji and Gbadamosi, (1999), who reported a strong positive correlation $(\mathrm{P}<0.05)$ between scrotal circumference and body weight at $r=0.70$ in Red Sokoto goats, and suggested that, testicular length and circumference are measures of testicular size which had been found to be significantly correlated with body weight; males with larger scrotal size might possess larger body size. Raji et al. (2008) reported that, the scrotal circumference and 
testes weight were significantly $(\mathrm{P}<0.05)$ higher in the Red Sokoto breed of goat when compared with another indigenous breed of goat in Nigeria. Similarly, Shamsuddin et al. (2000) reported correlation coefficient of $\mathrm{r}=0.95$ in the two parameters above in black Bengal goats.

A moderate positive correlation between the scrotal length and scrotal circumference was in agreement with the previous report of Raji et al. (2008), which stated that, scrotum length and scrotum circumference were found to be positively correlated with high correlation coefficients ranged from $r=0.61$ to $r=0.67$ in Red Sokoto and Borno white goats respectively. This implies the fact that selection of male goats based on scrotal circumference could be used as an indicator for breeding soundness evaluation under field condition. Result also revealed a significant $(\mathrm{P}<0.05)$ correlation between external pelvic circumference in Sahel does with body weight $(\mathrm{r}=0.40)$ and external pelvic circumference with body condition score $(\mathrm{r}=0.24)$, which concurs with other work conducted by Theodros, (2002), which reported that, body weight and external pelvic circumference were positively correlated $(\mathrm{r}=0.60)$ in Afar does in North eastern Ethiopia.

Dereje et al. (2013) reported a moderate correlation coeffici ent $(\mathrm{r}=0.55)$ between body weight and pelvic measurement, which provide a good predictor of live weight in Hararghe Highland Goat in Ethiopia, in the fields with no access to weighing scales.

\section{Conclusion}

In conclusion, the body weight, body condition score, height at withers, scrotal length, scrotal circumference and external pelvic circumference of Sahel goats in Maiduguri were successfully determined, these parameters studied might serve as a bases for determining the breeding soundness of Sahel Goats in the Arid zone of Nigeria. However, further studies relating to semen evaluation is recommended.

\section{Acknowledgements}

The Authors appreciate the contribution of Prof. M. M. Bukar for assisting in the analysis of our data. We are equally grateful to the Director, Veterinary Teaching Hospital, University of Maiduguri for the assistance rendered during sampling.

\section{Conflict of Interest}

The authors have no conflict of interest to declare.

\section{Authors Contributions}

AA, BUM and SOA collected the field data for the analysis, and wrote the initial draft for the manuscript. AM conceived the idea for manuscript development, MAW reviewed the manuscript, DI and IDP reviewed the literatures relating to past work. JS did the proof reading and final corrections of the manuscript. All authors approved the final draft.

\section{REFERENCES}

Abba, Y and Igbokwe, I.O. (2015). Testicular and related size evaluations in Nigerian Sahel Goats with optimal epididymal sperm. Veterinary Medicine International, 1-15.
Adedeji, O.S and Gbadamosi, A.J. (1999). Relationship of scrotal circumference, age, body weight and the right and left scrotal length in Red Sokoto (Maradi) goat. Proceeding of 26th Annual Nigerian Society of Animal Production (NSAP) Conference 21-25 March 1999: Ilorin, Nigeria. Pp 305-309.

Adeyinka, I.A and Mohammed, I. D. (2006). Relationship of live weight and linear body measurement in two breeds of goats of Northern Nigeria. Journal of Animal and Veterinary Advances, 5(11): 891-893.

Ahmed, A., Babiker, A., Gubartallal, A., Kamal, A. and Bakhiet, O. (2005). Comparative Studies on reproductive performance of Nubian and Saanen bucks under the climatic conditions of Khartoum. Journal Animal and Veterinary Advances. 4: 942944.

Ajani, S.O., Oyeyemi, M. O. and Olusoji, J. (2015). Correlation between weight, age, scrotal circumference and the testicular epididymal parameters of red Sokoto buck. Journal of Veterinary Medicine and Animal Health, 7 (5): 159163.

Alemayehu, T., Tikabo, G. and Gangwar, S.K. (2010). Application of linear body measurement for predicting body weight of Abergelle Goat breed in Tigray region Northern Ethiopia. Global Journal of Biological Science, 1(2):314-319.

Amare, E.G. and Kefelegn, W. (2017). Body weight and scrotal-testicular biometry in 3 indigenous breed of bucks in arid and semi-arid agro-ecologies, Ethiopia. Journal of Veterinary Medicine, 4: 1-9.

Amin, J.D., Waziri, M.A. and Ribadu, A. Y. (Eds) (2016). Dentition and ageing. In: Manual of Animal Restraint. Gabdel Integrated Service Publisher. 8789.

Babale, D.M., Abaya, U.H. and Gworgwor, Z. (2018). Relationship between liveweights, linear body measurements and cost prices of small ruminants sold in and around Mubi environs, Adamawa state, Nigeria. Journal of Dairy, Veterinary and Animal Research, 7 (6): 273-277.

Bukar, M. M., Amin, J.D., Sivachelvan, M.N. and Ribadu, A.Y. (2006). Postnatal histological development of the ovaries and uterus and the attainment of puberty in female kid goats. Small Ruminant Research, 65 (3): 200-208.

Bukar, M. M., Rosnina, Y., Wahid, H., Dhaliwal, G. K., Mohammed, A.G.K. and Ariff, O. M. (2012). Oestrus response and follicular development in Boer Does synchronized with flugestone acetate and PGF $\alpha$ or their combination with eCG or FSH. Tropical Animal Health and Production, 44: 15051511.

Burkholder, W.J. (2000). Condition scores in clinical assessment of the provision of optimal nutrition, American Journal of Veterinary Medicine Association, 2 (17): 650-665.

Dehouegnon, J. A., Tatiana, D. D. and Nazan, K. (2017). Recent Developments in Goat Farming and Perspectives for a Sustainable Production in Western Africa. International Journal of 
Environment, Agriculture and Biotechnology (IJEAB) 2 (4): 2047-205.

Dereje, T.1., Berhanu, B. and Aynalem, H. (2013). Linear Body Measurements as Predictor of Body Weight in Hararghe Highland Goats under Farmers Environment: Ethiopia. Global Veterinarian, 11 (5): 649-656.

Ebegbulem, V.N., Ibe, S.N., Ozung, P.O. and Ubua, J.A. (2011). Morphometric trait characteristics of West African Dwarf goats in Abia state, South East Nigeria. Continental Journal of Agricultural Science, 5 (2):1-6.

FAOSTAT (2008). Food and Agricultural Organization of the United Nations Statistics Division. FAO Statistic Retrieved.

Hifzan, R.M., Ismail, I. and Yaakub, H. (2015). Growth Pattern for Body Weight, Height at Withers and Body Length of Kalahari Red Goats. Pakistan Journal of Biological Sciences, 18: 200-203.

Jamie, L.S.and Clifford, F.S. (2014). Puberty and Estrus in Goats MSD and the MSD Veterinary Manual. Virginia-Maryland College of Veterinary Medicine.

Josue, C.V., Jennifer, M., Woodward, G., Curtis, P.V.T., Clet, W.M. and Max, F.R. (2018). Prediction of live weight of rural African goats using body measurement. Livestock Research for Rural Development, 30 (7): 60-68.

Kumbhar, U.B., Gulavane, S.U., Gaikwad, S.M., Lokhande, D.U., Ingole, S.D. and Sachdeva, G. (2017). Relationship of Ultrasonographic Testicular Biometry with Body Weight, Scrotal Circumference in Pre and Post Pubertal Osmanabadi Bucks. International Journal of Livestock Research, 7 (11) 206-208.

Kwari, H.D. (2001). A Morphological Study of the Ecotypes of Sahel Goats in Borno State with special reference to Sexual Dimorphism. Unpublished PhD Thesis, Department of Veterinary Anatomy, Faculty of Medicine, University of Maiduguri, Borno State Nigeria.

Memon, M.A., Mickelsen, W.D. and Goyal, H.O. (2007). Examination of reproductive tract and evaluation of potential breeding soundness in the bucks. Theriogenology, 2(4): 26-47.

Mohamed, G.H., Mohamed, S.E., Sayed, T. I. and Amal, M.E. (2020). Seasonal changes in testicular ultrasonogram pixel-intensity and their association with Semen characteristics in rams. Asian Pacific Journal of Reproduction. 9(1): 49-54.

Morand, F., Boutonnet, J., Devendra, C., Dubeuf, J., Haenlein, G.F.W., Mowlem, L. and Capote, J. (2004). Strategy for goat farming in the $21 \mathrm{st}$ century. Small Ruminant Research, 51; 175-184.

Muhammad, F., Khan, H.and Zubair, M. (2006). Relationship of body weight with linear body measurements in Goats. Journal of Animal and Veterinary Advances, 5: (6) 452-455.

Nongo, N.N. and Akinboade, O.A. (2013). Goat Weights Obtained from Innovated and Two Other Scales Prior to Experimental Trypanosome Infection.
Journal of Biology, Agriculture and Healthcare. 3 (2), 2-5.

Okpeku, M., Yakubu, A., Peters, S.O., Ozoje, M.O., Ikeobi, C.O.N., Adebambo, O. A. and Imumorin, I.G. (2011). Application of multivariate principal component analysis to morphological characterization of indigenous goats in Southern Nigeria. Acta Agriculturae Slovenica. 98(2):101109.

Onakpa, A., Adeyinka, I. A. and Mohammed, I.D. (2010). Relationship of live weight and linear body measurement in two breeds of goats of Northern Nigeria. Journal of Animal and Veterinary Advances, 5(11): 891-893.

Oyeyemi, M. O., Leigh, O. O. and Fakayode, A. (2011). Spermiogram and Changes in Body Parameters of West African Dwarf Bucks Fed with Dussa-poultry. Journal of Animal and Veterinary Advances, 5:891893.

Raji, A.O., Igwebuike, J. U. and Aliyu, J. (2008). Testicular biometry and its relationship with body weight of indigenous goats in a semiarid region of Nigeria. Journal of Agriculture Biological Science, 3:35-8.

Salako, A.E. (2004). Maturity rate of some morphometric traits in the West African Dwarf Sheep of Nigeria. Tropical Journal of Animal Science, 7(1): 51-55.

Sameh, S., Farida, A.B., Zoubir, B., Houria, O.and Amel, D. (2019). Testicular Biometry and its Relationship with Age and Body Weight of Indigenous Bucks (Algeria). Advances in Animal and Veterinary Sciences, 7 (10): 882.

Samuel, O.K.and Salako, A. (2008). Body measurement characteristics of the West African Dwarf (WAD) Goat in deciduous forest zone of Southwestern Nigeria. African. Journal of Biotechnology, 7(14): 2521-2526.

Shamsuddin, M., Amiri, Y. and Bhuiyan, M.M.U. (2000). Characteristics of buck semen with regard to ejaculate numbers, collection intervals, dilution and preservation periods. Reproduction in Domestic Animals, 35:53-57.

Theodros, T. (2002). Predicting live weight using body measurements in Afar goats in north eastern Ethiopia. Momona Ethiopian Journal of Science (MEJS), 6 (2): 18-32.

Turkgeldi, I., Arik, I.Z., Yurtman, M. O. and Ozduven, M. L. (1997). Relations between body eight and condition score Akdeniz University. Journal of Agriculture Faculty of Animal Science Department, 10: 129135.

USDA, (2019). Goat dentition. Cooperative Extension. United State Department of Agriculture, National institute of food and Agriculture. https://goats.extension.org/goat. 